\title{
TIME TRENDS IN ABILITY LEVEL AND FUNCTIONAL OUTCOME OF STROKE AND MULTIPLE SCLEROSIS PATIENTS UNDERGOING COMPREHENSIVE REHABILITATION IN SLOVENIA ČASOVNE SPREMEMBE NIVOJA ZMOŽNOSTI IN FUNKCIJSKEGA IZIDA BOLNIKOV PO MOŽGANSKI KAPI IN Z MULTIPLO SKLEROZO NA CELOSTNI REHABILITACIJI V SLOVENIJI
}

\author{
Gaj Vidmar' ${ }^{1}$, Helena Burger ${ }^{1}$, Črt Marinček ${ }^{1}$
}

Prispelo: 1. 2. 2010 - Sprejeto: 4. 7. 2010

Original scientific article UDC 615.851.3:616.8

\begin{abstract}
Background: The University Rehabilitation Institute in Ljubljana provides comprehensive rehabilitation for the whole territory of Slovenia. The aim of the study was to verify a clinical observation that the demandingness of rehabilitation has been increasing because of a decrease in patients' functional abilitites on admission, with rehabilitation outcomes having remained unchanged or even improved.

Methods: Functional Independence Measure (FIM) scores of 651 cerebrovascular insult (CVI) and 151 multiple sclerosis (MS) patients gathered between September 2004 and September 2006 (all eligible cases) were compared with those for patients with the same diagnosis ( $N=144$ and 74 , respectively) collected during the period from September 1999 to September 2000 (a random sample), considering only first-admission cases. The average FIM (motor, cognitive and total) scores and FIM gain after rehabilitation during the two periods were determined for each diagnostic group adjusted for patient age. Rehabilitation efficiency and effectiveness levels were compared in the same way. Effect Size and Standardised Response Mean were also analysed.

Results: There were no differences in gender structure of the groups between the periods studied. During the recent period, the average age was higher by around two years in both groups. The length of stay was marginally shortened for CVI patients and remained unchanged for MS patients. There were no differences between the two periods concerning the time elapsed since stroke. In both groups, admission motor and cognitive FIM scores were on average approximately five points lower in the recent period, while the average rehabilitation gain from admission to discharge increased over time (in total by 1 in CVI patients and by 3 in MS patients). Regarding motor and total FIM scores, the standardised gain, rehabilitation efficiency and rehabilitation effectiveness increased as well. Conclusions: The Institute is admitting more severely affected patients than it did five to ten years ago, and parallelly the patient age has increased. Despite that and notwithstanding the tendency towards shorter rehabilitation, expected age-adjusted functional independence gain, rehabilitation efficiency, rehabilitation effectiveness, and the standardised functional independence gain have increased.
\end{abstract}

Key words: stroke, multiple sclerosis, outcome and process assessment (health care), rehabilitation centers

Izvirni znanstveni članek UDK 615.851.3:616.8

Izvleček

Izhodišča: Univerzitetni rehabilitacijski inštitut v Ljubljani nudi kompleksno rehabilitacijo za celotno ozemlje 
Slovenije. Želeli smo preveriti klinične izkušnje, da zahtevnost rehabilitacije narašča zaradi vse manjših funkcijskih zmožnosti bolnikov ob sprejemu, hkrati pa se izidi rehabilitacije ne slabšajo ali se celo izboljšujejo.

Metode: Dosežke na Lestvici funkcijske neodvisnosti (Functional Independence Measure - FIM) pri 651 bolnikih po možganski kapi (CVI) in 151 bolnikih z multiplo sklerozo (MS), zbrane v obdobju IX/2004-IX/2006 (vsi ustrezni bolniki), smo primerjali z bolniki z istima diagnozama ( $N=144$ in 74 ) iz obdobja IX/1999-IX/2000 (slučajni vzorec), pri čemer smo upoštevali le prve sprejeme. Povprečni dosežek na FIM (na motorični in kognitivni podlestvici ter skupni lestvici) in porast FIM po rehabilitaciji smo primerjali med obdobjema znotraj vsake diagnostične skupine, pri čemer smo odstranili vpliv starosti bolnikov. Učinkovitost in uspešnost rehabilitacije smo primerjali na enak način. Analizirali smo tudi velikost učinka in standardizirani povprečni odziv.

Rezultati: Struktura spola se med obdobjema ni razlikovala $v$ nobeni skupini. Povprečna starost je bila $v$ obeh skupinah višja za okoli 2 leti v novejšem obdobju. Ležalna doba se je nekoliko skrajšala za bolnike $s$ CVI, za bolnike z MS pa se ni spremenila. Čas od kapi se med obdobjema ni razlikoval. V obeh skupinah so bili dosežki na motorični in kognitivni podlestvici FIM ob sprejemu v povprečju za okoli 5 točk nižji v novejšem obdobju, hkrati pa se je povprečni porast od sprejema do odpusta povečal (skupaj za okoli 1 pri CVI in okoli 3 pri MS). Glede motoričnega in skupnega dosežka na FIM so se s časom povečali tudi standardizirani porast, učinkovitost rehabilitacije in uspešnost rehabilitacije.

Zaključek: Na našem inštitutu sprejemamo zahtevnejše bolnike kot pred 5-10 leti, kar spremlja povečanje njihove starosti. Kljub temu in težnji po skrajševanju ležalne dobe so se pričakovani starostno neodvisni porast funkcijske neodvisnosti, učinkovitost rehabilitacije in uspešnost rehabilitacije povečali, kar velja tudi za standardizirani porast funkcijske neodvisnosti.

Ključne besede: možganska kap, multipla skleroza, ocenjevanje izidov in postopkov v zdravstvu, rehabilitacijski centri

\section{Introduction}

The Functional Independence Measure (FIM) scale is arguably the main outcome measure in rehabilitation medicine (1) and an important casemix tool (2). It was devised in 1984 at a workshop held by the American Congress for Rehabilitation Medicine and the American Academy of Physical Medicine and Rehabiltiation to be used as a universal assessment tool in the medical rehabilitation Uniform Data System (UDS) $(3,4)$. Its use in patients with various pathologies and for various purposes has since been reported in over one thousand articles, counting only those abstracted in the PubMed/MEDLINE bibliographic database. The FIM is used for evaluation of disability in stroke (5), traumatic brain injury (6), multiple sclerosis (7), in patients after trauma $(8,9)$, in patients with Parkinson disease (10) and other pathologies in order to identify rehabilitation needs (11), demonstrate effectiveness of rehabilitation interventions $(7,12)$, compare rehabilitation programmes in different areas (13), as well as to predict functional independence at discharge (14) and in the longer term (9).

The FIM has demonstrated acceptable reliability across a wide variety of settings, assessors and patients (15). In neurological patients, it has been found to be more valid than the Barthel Index and equally reliable in the assessment of disability (4). Stineman (16) demonstrated reliability, item internal consistency and item discriminant validity in 20 impairment categories. Later studies revealed some problems in comparing raw FIM data in different countries $(17,18)$, yet the validity is unquestionable in comparisons within a country (within the same hospital), as is the case in our study. FIM has two dominant subdomains of difficulty, one for the motor items and the other for the cognitive items. The patterns are consistent although not identical across impairment groups $(19,20)$ and differences exist in this regards between countries $(17,18)$, but those concerns do not affect our study, either.

The University Rehabilitation Institute in Ljubljana (URI) is the only tertiary health care institution in the field of physical and rehabilitation medicine in Slovenia and the only rehabilitation hospital in the country. As such, it provides comprehensive rehabilitation for the whole territory of Slovenia, admitting about 1300 cases per year. Compulsory FIM assessment at admission and discharge, integrated into the hospital information system, was introduced in 2004. This study used these FIM data and a cross-sectional comparison with the historical data available in order to verify a clinical observation that rehabilitation demandingness has been increasing because of increasing numbers of patients with lower admission functional ability. 
Another aim was to determine possible differences in rehabilitation effects, taking into account patient demographics, duration of rehabilitation and potential for measured progress given the FIM score at admission.

\section{Materials and Methods}

\subsection{Research design and subjects}

FIM scores of patients with cerebrovascular insult (CVI) and multiple sclerosis (MS) gathered between September 2004 and September 2006 were compared to those of patients with the same diagnosis, collected between September 1999 and September 2000 ( $\mathrm{N}=144$ and 74 for $\mathrm{CVI}$ and MS, respectively). Data for the earlier period were obtained within the PRO-ESOR international research project (21). Those were all first admission cases, so only first admission cases were selected from the 2004-2006 period ( $\mathrm{N}=651$ and 151 for $\mathrm{CVI}$ and MS, respectively). The same admission criteria applied for both time periods:

- For CVI-stable neurological condition; considerable and non-diminishing neurological deficits; at least two areas of impairment among ambulation, daily activities, continence, cognitive abilities, communication, swollowing, and pain syndrome; sufficient cognitive ability for learning; adequate communication ability (preferably ability to follow two- or three-way instructions); physical ability to participate in active programmes for at least three hours daily.

- For MS - worsened functional status, especially regarding daily activities or ambulation; or need for fitting advanced technical aids; or need for advanced therapeutic interventions for spasticity or pain.

A random sample of eligible cases was selected during the period 1999-2000. The sample size was designed to meet the needs of the research project and was limited by the resources available. For the 2004-2006 period, all eligible cases were retrieved from the hospital information system. The study protocol was approved by the Medical Ethics Committee of the University Rehabilitation Institute, Republic of Slovenia. Because of the retrospective documentation-based nature of the study, no informed patient consent was needed.

\subsection{Derived outcome measures}

In order to allow a more direct comparison between periods, mean admission-to discharge changes in
FIM scores were standardised using the following two common measures (22):

- Effect Size (ES, also known as Cohen's d), computed as the mean change divided by the standard deviation at admission;

- Standardised Response Mean (SRM), computed as the mean change divided by the standard deviation of change.

In addition to FIM scores two outcomes were calculated and analysed in order to take into account the duration of rehabilitation and the reduced potential for observing functional gain in patients with higher admission scores, respectively (23):

- Rehabilitation efficiency is the amount of change averaged over the duration of rehabilitation, i.e., the increase in functional ability per day of stay;

- Rehabilitation effectiveness is the proportion of potential improvement obtained during rehabilitation, calculated as the difference between discharge and admission scores, divided by the maximum potential improvement (i.e. difference between maximum possible score and admission score).

\subsection{Statistical analysis}

Descriptive statistics and graphical displays were produced for all the variables studied. Possible differences between both time periods as concerns gender structures within each diagnostic group were assessed using the Fisher's exact test. The two-sample $t$-test was employed to compare the average patient age and the average length of stay, and the MannWhitney test was used to compare times elapsed since stroke. Because of differences in the average age between the periods studied (see Results), analysis of covariance (ANCOVA) was used to determine possible differences between the two time periods in average age-adjusted FIM scores (motor, cognitive and total) within each diagnostic group. Since rehabilitation efficiency and effectiveness data clearly violate the assumptions of such parametric analysis, those variables were age-adjusted by first fitting a robust linear regression (iteratively reweighted least squares using Huber $M$-estimator (24)) model and then testing the differences between periods on the residuals from that model using exact nonparametric Mann-Whitney test. Statistical analyses were conducted using SPSS Statistics 17.0.1 (SPSS Inc., Chicago, IL, USA, 2008), whereby robust regression was performed with the SPSSINC ROBUST REGR extension command that uses the $R$ (25) plugin to execute the $\mathrm{r} / \mathrm{m}$ function from the MASS package (26). $P$-values $\leq 0.05$ were considered statistically significant. 


\section{Results}

Men accounted for $62 \%$ of the CVI patients in the 1999 2000 sample (71 men vs. 43 women) and for $61 \%$ in the 2004-2006 sample (396 men vs. 255 women; $p=0.835$ for the difference between periods). Women prevailed among the MS patients - there were $62 \%$ of women in the 1999-2000 sample (45 women vs. 29 men) and $70 \%$ in the 2004-2006 sample (106 women vs. 45 men; $p=0.176$ for the difference between periods).

A difference in the age of both groups was observed between the two periods: the average age of $\mathrm{CVI}$ patients was 57.9 years (SD 11.1) in the period 1999-2000, and 60.4 years (SD 13.0) in the period 2004-2006 ( $p=0.049$ from the two-sample $t$-test). The average age of MS patients was 48.3 years (SD 14.3) in the period $1999-2000$ and 50.9 years (SD 12.6) in the period from 2004 to 2006 ( $p=0.164)$.

There was no significant difference in the length of stay of CVI patients (Figure 1) between the two periods, although a trend towards a shorter rehabilitation is observed (1999-2000: mean 50.2 days, SD 21.4 days; 2004-2006: mean 45.6 days, SD 20.5 days; $p=0.107)$. For MS patients, the average length of rehabilitation remained unchanged (1999-2000: mean=25.2 days, $S D=10.4$ days; 2004-2006: mean=25.3 days, $\mathrm{SD}=10.7$ days; $p=0.938$ ). For $\mathrm{CVI}$ patients, there was no difference in times since stroke between the two periods (1999-2000: median=6.0 months, 2004-2006: median=5.0 months; $p=0.200$ ).

Comparisons between the time periods regarding FIM scores are summarised in Table 1 and Figure 2. In both groups, admission motor and cognitive subscale scores were on average 5 points lower in the 2004-2006 period, the average total score being approximately 10 points lower. The average difference between discharge and admission scores had increased over time, in total by about 1 and 3 points in CVI and MS patients, respectively. Lack of a statistically significant interaction effect implies that the observed differences do not vary with patient age.

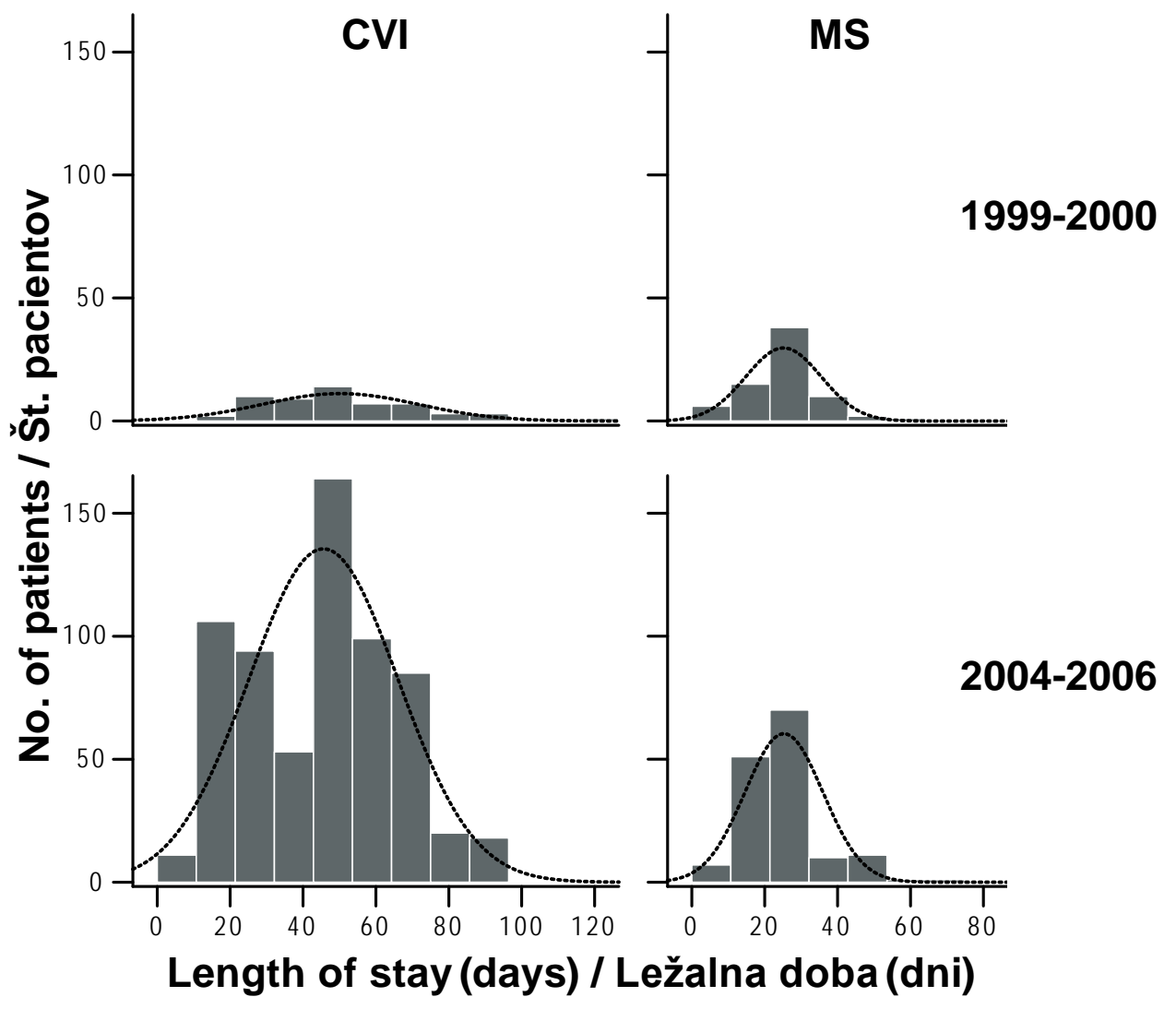

Figure 1. Distribution of length of stay (with superimposed fitted normal distribution) of stroke (CVI) and multiple sclerosis (MS) patients during the 1999-2000 and 2004-2006 periods.

Slika 1. Porazdelitev ležalne dobe (z dodano najbolje prilegajočo se normalno porazdelitvijo) v obdobju 1999-2000 in 2004-2006 za bolnike po možganski kapi (CVI) in z multiplo sklerozo (MS). 
The results of rehabilitation efficiency and effectiveness analyses are summarised in Table 2. In CVI patients, we found a marginally significant increase in efficiency and no noteworthy changes in effectiveness. In MS patients, both efficiency and effectiveness significantly increased over the time period observed.

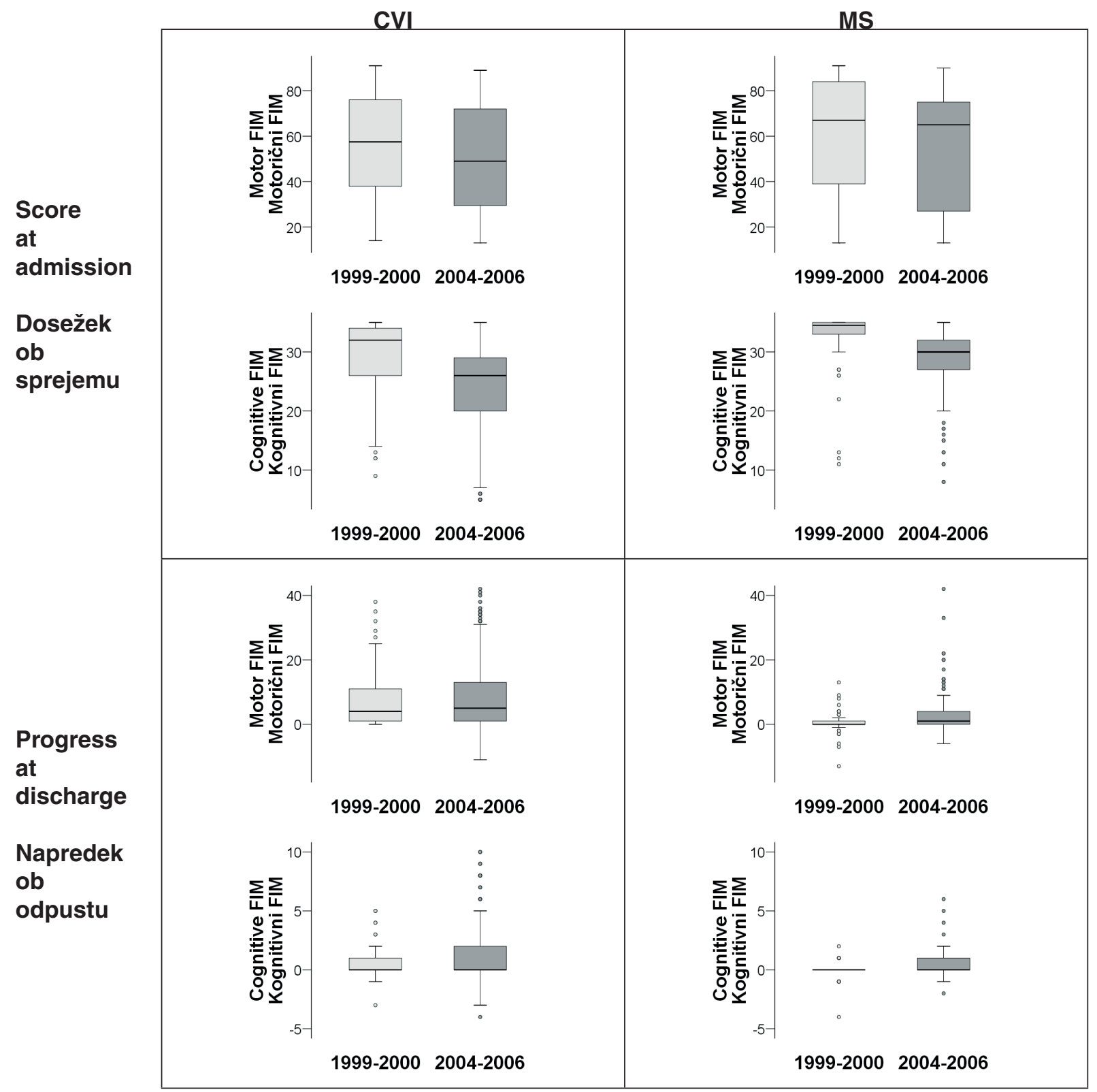

Figure 2. Boxplots depicting distribution of motor and cognitive FIM subscale scores at admission, and of progress level at discharge for stroke (CVI) and multiple sclerosis (MS) patients, for the periods 1999-2000 and 2004-2006. Thick line denotes the median; the box denotes the interquartile range (IQR); whiskers indicate the non-outlier range (smallest and largest observed value within 1.5 IQR below and above the 1st and 3rd quartiles, respectively); and the circles indicate the outliers.

Slika 2. Škatlasti diagrami za prikaz porazdelitve dosežkov na motorični in kognitivni podlestvici FIM ob sprejemu ter napredka ob odpustu v obdobju 1999-2000 in 2004-2006 za bolnike po možganski kapi (CVI) in z multiplo sklerozo (MS). Debela črta označuje mediano; škatla označuje interkvartilni razmik (IKR); ročaji označujejo razpon brez odstopajočih vrednosti (najmanjšo in največjo opaženo vrednost znotraj 1,5 IKR pod oziroma nad 1. oziroma 3. kvartilom); krožci označujejo osamelce. 
Table 1. Descriptive statistics and statistical significance of differences between the 1999-2000 and the 2004-2006 periods regarding admission FIM scores and progress in FIM scores at discharge, for stroke (CVI) and multiple sclerosis (MS) patients.

Tabela 1. Opisne statistike in statistična značilnost za primerjavo med obdobjema 1999-2000 in 2004-2006 glede dosežka na FIM ob sprejemu in napredka $v$ dosežku na FIM ob odpustu za bolnike po možganski kapi (CVI) in z multiplo sklerozo (MS).

\begin{tabular}{|c|c|c|c|c|c|c|}
\hline \multirow{2}{*}{\multicolumn{2}{|c|}{$\begin{array}{l}\text { FIM score } \\
\text { Dosežek na FIM }\end{array}$}} & \multirow{3}{*}{$\begin{array}{c}\text { Group } \\
\text { Skupina } \\
\text { CVI }\end{array}$} & \multirow{3}{*}{$\begin{array}{c}\begin{array}{c}\text { Period } \\
\text { Obdobje }\end{array} \\
1999-2000 \\
2004-2006\end{array}$} & \multirow{3}{*}{$\begin{array}{c}\text { Mean } \pm \text { SE } \\
\text { Povp. } \pm \text { St.nap. } \\
83.91 \pm 2.48 \\
74.90 \pm 1.03\end{array}$} & \multicolumn{2}{|c|}{$\begin{array}{c}p \text { for the effect of } \\
p \text { za učinek }\end{array}$} \\
\hline & & & & & Period & Interaction \\
\hline \multirow{3}{*}{$\begin{array}{l}\text { FIM score on } \\
\text { admission }\end{array}$} & \multirow{2}{*}{$\begin{array}{l}\text { Total } \\
\text { Skupni }\end{array}$} & & & & 0.001 & 0.685 \\
\hline & & MS & $\begin{array}{l}1999-2000 \\
2004-2006\end{array}$ & $\begin{array}{l}92.09 \pm 3.45 \\
83.00 \pm 2.56\end{array}$ & 0.036 & 0.247 \\
\hline & \multirow{2}{*}{$\begin{array}{c}\text { Motor } \\
\text { Motorični }\end{array}$} & CVI & $\begin{array}{l}1999-2000 \\
2004-2006\end{array}$ & $\begin{array}{l}54.41 \pm 2.06 \\
50.62 \pm 0.85\end{array}$ & 0.089 & 0.752 \\
\hline \multirow{3}{*}{$\begin{array}{l}\text { Dosežek } \\
\text { ob } \\
\text { sprejemu }\end{array}$} & & MS & $\begin{array}{l}1999-2000 \\
2004-2006\end{array}$ & $\begin{array}{l}59.64 \pm 3.02 \\
54.70 \pm 2.24\end{array}$ & 0.191 & 0.201 \\
\hline & \multirow{2}{*}{$\begin{array}{l}\text { Cognitive } \\
\text { Kognitivni }\end{array}$} & CVI & $\begin{array}{l}1999-2000 \\
2004-2006\end{array}$ & $\begin{array}{l}29.49 \pm 0.64 \\
24.28 \pm 0.27\end{array}$ & $<0.001$ & 0.582 \\
\hline & & MS & $\begin{array}{l}1999-2000 \\
2004-2006 \\
\end{array}$ & $\begin{array}{l}32.45 \pm 0.65 \\
28.30 \pm 0.49\end{array}$ & $<0.001$ & 0.837 \\
\hline \multirow{6}{*}{$\begin{array}{l}\text { Progress } \\
\text { at } \\
\text { discharge }\end{array}$} & \multirow{2}{*}{$\begin{array}{l}\text { Total } \\
\text { Skupni }\end{array}$} & $\mathrm{CVI}$ & $\begin{array}{r}1999-2000 \\
2004-2006 \\
\end{array}$ & $\begin{array}{l}8.75 \pm 1.45 \\
9.56 \pm 0.41\end{array}$ & 0.586 & 0.347 \\
\hline & & MS & $\begin{array}{r}1999-2000 \\
2004-2006 \\
\end{array}$ & $\begin{array}{l}0.47 \pm 0.68 \\
3.77 \pm 0.50\end{array}$ & $<0.001$ & 0.964 \\
\hline & \multirow{2}{*}{$\begin{array}{c}\text { Motor } \\
\text { Motorični }\end{array}$} & CVI & $\begin{array}{l}1999-2000 \\
2004-2006\end{array}$ & $\begin{array}{l}8.41 \pm 1.35 \\
8.40 \pm 0.38\end{array}$ & 0.989 & 0.440 \\
\hline & & MS & $\begin{array}{l}1999-2000 \\
2004-2006\end{array}$ & $\begin{array}{l}0.52 \pm 0.67 \\
3.36 \pm 0.49\end{array}$ & 0.001 & 0.793 \\
\hline & \multirow{2}{*}{$\begin{array}{l}\text { Cognitive } \\
\text { Kognitivni }\end{array}$} & CVI & $\begin{array}{l}1999-2000 \\
2004-2006 \\
\end{array}$ & $\begin{array}{l}0.34 \pm 0.30 \\
1.17 \pm 0.09\end{array}$ & 0.007 & 0.281 \\
\hline & & MS & $\begin{array}{l}1999-2000 \\
2004-2006\end{array}$ & $\begin{array}{l}-0.05 \pm 0.11 \\
0.42 \pm 0.08\end{array}$ & 0.001 & 0.053 \\
\hline
\end{tabular}

Efficiency and effectiveness analyses necessarily exclude the patients who were admitted with the maximum possible score. Regarding the total score and the motor subscale, there were two such patients during the period 1999-2000, and none in the period 2004-2006, neither in the CVI group nor in the MS group. The figure is considered negligible for the purpose of our study. For the cognitive subscale, the proportion was generally higher and statistically significantly higher for the period 1999-2000 than for the period $2004-2006$ (22\% vs. $3 \%$ in the CVI group,
$50 \%$ vs. $10 \%$ in the MS group, $p<0.001$ from Fisher's exact test). Hence, the comparisons reported above in relation to Table 2 are only unquestionably valid for - and primarily refer only to - the total score and the motor subscale score.

Standardised FIM change measures are reported in Table 3. For the total score and for both subscale scores, both standardised change measures were larger for the recent period in both groups (with the sole exception of the effect size for motor score in CVI patients). 
Table 2. Descriptive statistics and statistical significance of differences between the 1999-2000 and 20042006 periods regarding the rehabilitation efficiency and effectiveness, calculated from FIM scores, for stroke (CVI) and multiple sclerosis (MS) patients.

Tabela 2. Opisne statistike in statistična značilnost za primerjavo med obdobjema 1999-2000 in 2004-2006 glede učinkovitosti in uspešnosti rehabilitacije, izračunane na podlagi dosežkov na FIM, za bolnike po možganski kapi (CVI) in z multiplo sklerozo (MS).

\begin{tabular}{|c|c|c|c|c|c|c|c|}
\hline \multirow{2}{*}{\multicolumn{2}{|c|}{$\begin{array}{l}\text { Me }(Q 1, Q 3) \\
\text { FIM }\end{array}$}} & \multicolumn{3}{|c|}{$\begin{array}{l}\text { Efficiency } \\
\text { Učinkovitost }\end{array}$} & \multicolumn{3}{|c|}{$\begin{array}{c}\text { Effectiveness } \\
\text { Uspešnost }\end{array}$} \\
\hline & & \multirow{2}{*}{\begin{tabular}{|c}
$\begin{array}{c}\text { Total } \\
\text { Skupni }\end{array}$ \\
$9.4 \%$ \\
$(3.4 \%, 21.3 \%)$
\end{tabular}} & \multirow{2}{*}{$\begin{array}{c}\begin{array}{c}\text { Motor } \\
\text { Motorični }\end{array} \\
8.3 \% \\
(2.2 \%, 19.3 \%)\end{array}$} & \multirow{2}{*}{\begin{tabular}{|c}
$\begin{array}{c}\text { Cognitive } \\
\text { Kognitivni }\end{array}$ \\
$0.0 \%$ \\
$(0.0 \%, 1.4 \%)$
\end{tabular}} & \multirow{2}{*}{$\begin{array}{c}\begin{array}{c}\text { Total } \\
\text { Skupni }\end{array} \\
23.5 \% \\
(5.7 \%, 42.4 \%)\end{array}$} & \multirow{2}{*}{$\begin{array}{c}\begin{array}{c}\text { Motor } \\
\text { Motorični }\end{array} \\
23.2 \% \\
(3.9 \%, 43.3 \%)\end{array}$} & \multirow{2}{*}{$\begin{array}{c}\begin{array}{c}\text { Cognitive } \\
\text { Kognitivni }\end{array} \\
0.0 \% \\
(0.0 \%, 33.3 \%)\end{array}$} \\
\hline CVI & $\begin{array}{l}1999- \\
2000\end{array}$ & & & & & & \\
\hline & $\begin{array}{l}2004- \\
2006\end{array}$ & $\begin{array}{c}15.2 \% \\
(5.1 \%, 28.3 \%)\end{array}$ & $\begin{array}{c}12.0 \% \\
(3.1 \%, 25.6 \%)\end{array}$ & $\begin{array}{c}0.0 \% \\
(0.0 \%, 4.3 \%)\end{array}$ & $\begin{array}{c}18.5 \% \\
(4.3 \%, 33.3 \%)\end{array}$ & $\begin{array}{c}19.0 \% \\
(3.0 \%, 38.2 \%)\end{array}$ & $\begin{array}{c}0.0 \% \\
(0.0 \%, 25.0 \%)\end{array}$ \\
\hline \multicolumn{2}{|l|}{$p$} & 0.070 & 0.215 & 0.021 & 0.148 & 0.285 & 0.947 \\
\hline \multirow[t]{2}{*}{ MS } & $\begin{array}{l}1999- \\
2000\end{array}$ & $\begin{array}{c}0.0 \% \\
(0.0 \%, 5.8 \%)\end{array}$ & $\begin{array}{c}0.0 \% \\
(0.0 \%, 5.8 \%)\end{array}$ & $\begin{array}{c}0.0 \% \\
(0.0 \%, 0.0 \%)\end{array}$ & $\begin{array}{c}0.0 \% \\
(0.0 \%, 4.2 \%)\end{array}$ & $\begin{array}{c}0.0 \% \\
(0.0 \%, 3.7 \%)\end{array}$ & $\begin{array}{c}0.0 \% \\
(0.0 \%, 0.0 \%)\end{array}$ \\
\hline & $\begin{array}{l}2004- \\
2006\end{array}$ & $\begin{array}{c}8.0 \% \\
(2.2 \%, 18.4 \%)\end{array}$ & $\begin{array}{c}4.3 \% \\
(0.0 \%, 16.7 \%)\end{array}$ & $\begin{array}{c}0.0 \% \\
(0.0 \%, 4.2 \%)\end{array}$ & $\begin{array}{c}6.7 \% \\
(1.3 \%, 17.2 \%)\end{array}$ & $\begin{array}{c}4.3 \% \\
(0.0 \%, 16.7 \%)\end{array}$ & $\begin{array}{c}0.0 \% \\
(0.0 \%, 21.7 \%)\end{array}$ \\
\hline$p$ & & $<0.001$ & 0.002 & $<0.001$ & $<0.001$ & $<0.001$ & 0.003 \\
\hline
\end{tabular}

Note: Values are reported as the median (1st quartile, 3rd quartile).

Opomba: Vrednosti so prikazane kot mediana (1. kvartil, 3. kvartil).

Table 3. Standardised FIM change measures for the periods 1999-2000 and 2004-2006, for stroke (CVI) and multiple sclerosis (MS) patients.

Tabela 3. Standardizirane mere spremembe dosežka na FIM za obdobji 1999-2000 in 2004-2006 za bolnike po možganski kapi (CVI) in z multiplo sklerozo (MS).

\begin{tabular}{|l|c|c|c|c|c|c|c|}
\hline \multirow{2}{*}{$\begin{array}{l}\text { Group } \\
\text { Skupina }\end{array}$} & \multirow{2}{*}{$\begin{array}{c}\text { Period } \\
\text { Obdobje }\end{array}$} & \multicolumn{2}{|c|}{$\begin{array}{c}\text { Total FIM } \\
\text { Skupni FIM }\end{array}$} & \multicolumn{2}{c|}{$\begin{array}{c}\text { Motor FIM } \\
\text { Motorični FIM }\end{array}$} & \multicolumn{2}{c|}{$\begin{array}{c}\text { Cognitive FIM } \\
\text { Kognitivni FIM }\end{array}$} \\
\cline { 3 - 8 } & & ES & SRM & ES & SRM & ES & SRM \\
\hline \multirow{2}{*}{ CVI } & $\mathbf{1 9 9 9 - 2 0 0 0}$ & 0.348 & 0.757 & 0.385 & 0.729 & 0.093 & 0.333 \\
\cline { 2 - 8 } & $2004-2006$ & 0.357 & 0.952 & 0.373 & 0.904 & 0.174 & 0.546 \\
\hline \multirow{2}{*}{ MS } & $\mathbf{1 9 9 9 - 2 0 0 0}$ & 0.018 & 0.143 & 0.021 & 0.165 & -0.008 & -0.063 \\
\cline { 2 - 8 } & $\mathbf{2 0 0 4 - 2 0 0 6}$ & 0.133 & 0.621 & 0.134 & 0.541 & 0.094 & 0.538 \\
\hline
\end{tabular}

Legend: $E S=$ effect size; $S R M=$ standardised response mean.

Legenda: $E S=$ =elikost učinka; $S R M=$ standardizirani povprečni odziv. 


\section{Discussion}

It is evident that today, at least as concerns CVI and MS cases, more severely affected patients are admitted than five to ten years ago. Because of S-shaped nonlinearity of the FIM scale (20), the actual difference in ability may differ somewhat from what the FIM scores show, but a difference certainly exists over and above the increasing patient age. At least in CVI patients, this cannot be attributed to earlier admissions after stroke.

A critical observation that can be made is that the interval level of measurement is questionable for FIM (sub)scores: they are obtained by summation of ordinal-level items (27), so subtracting them or dividing them by a truly numeric quantity - be it for the purpose of calculating a $t$-test or deriving standardised change measures (28) - is not recommended. However, the approach we adopted is a widespread practice, empirically verified to produce small errors, and the classical test theory is a sufficiently valid framework for the aim of our study, which is a practical decision support cum grano salis comparable to the Shewhart's and Deming's spirit of Statistical Process Control, or better yet, Wheeler's concept of Continual Improvement (29).

It should also be recognised that, in general, FIM scores (particularly the cognitive subscale) are subject to a ceiling effect, and that they exhibit a distinctly bimodal distribution in our patient population (30). This is well-modelled by a mixture of around one third of patients with a mean of aroud 60, SD of around 25 and expected gain of around 10 on admission; and around two thirds of patients with a mean of around 105, SD around 10 and expected gain of approximately 5 on admission (31). Nevertheless, the reported means and standard deviations provide a useful description of the data because of a reasonable symmetry of the observed FIM score distributions in the two groups studied. Similarly, given the relatively large samples, fairly homogeneous FIM score variances across age groups, and bell-shaped age distributions in both groups, the analysis of covariance performed yields sufficiently valid significance tests (32).

Furthermore, the presented findings are in agreement with other time-trend analyses, conducted at this Institute for the purpose of quality control, internal auditing and funding issues. Those analyses indicated an increasing ratio of tetraplegia vs. paraplegia among the patients with spinal cord injury (from around 1:5 before 2004 to around $4: 3$ in 2006; $p<0.001$ from the Fisher-Freeman-Halton exact test), a decreasing length of stay on hospital level (median decreasing from 23.2 days in 2000 to 17.6 days in 2007; negative slope from LOESS regression throughout the period), and increasing rates of complications and concomitant diagnoses in all departments (by approx. $20 \%$ between 2001 and 2007; $p<0.05$ for comparisons of Poisson rates).

Despite such trends, the expected age-adjusted functional independence gain during rehabilitation, assessed by by the FIM progress, has not decreased but has even slightly increased. For the motor subscale, the difference in progress between the time periods studied was only statistically significant in the MS group, while for the cognitive FIM subscale it was statistically significant for both groups, an observation that is partly an artefact due to a ceiling effect, but nevertheless constitutes evidence against an undesired trend if not proper evidence for a desired trend. Further light is shed on this issue by assessments of rehabilitation efficiency and effectiveness, which - though limited in validity to total and motor scores - demonstrate a marginally significant progress in efficiency in the CVI group and a clearly significant progress in both measures for the MS group.

Standardised change scores provide the same picture. Again, they are mainly relevant only for the total and the motor scores, and should be interpreted with caution $(33,34)$, including avoiding categorising the observed SRM values into the Cohen's size-classes. Nevertheless, they offer additional grounds for our overall conclusions to be drawn.

On a final note, we cannot ignore the possibility that the observed differences are at least partly attributable to the assessment bias. All assessors had completed the same formal FIM training, but different assessors participated during the two periods studied (except for two phisicians who were among the four assessors during the first period and among the assessors during the second period; and even those two had gained further experience after the first period). The possibility of bias should be addressed because after the initial report on a very high interrater reliability and high test-retest and equivalence reliability of summary FIM scores prepared by four formally trained assessors regarding summary FIM scores (15), a moderate interrater agreement on FIM items (even in its modified version based on Rasch analysis) was emphasised in various settings and contexts (35-39). However, at least for the first time period studied the item-response approach proved that our assessors appropriately used all seven levels of each item in accordance with the patients' functional independence 
(21). Furthermore, as admitted in the recent report on considerable discrepancies at the item level (39), it is reasonable to expect the individual item variation can be smoothed by a sufficiently large number of FIM items (especially for the total and motor scores), thus yielding sufficient summary score agreement.

\section{Conclusion}

Our findings can be related to the global trends in population ageing and to progress of medicine, resulting in older and more severely ill patients being admitted to tertiary hospitals. It is encouraging that despite such trends, the expected functional independence gain, as well as rehabilitation efficiency and effectiveness assessed at this Institute have increased, at least as indicated by total and cognitive FIM scores, and at least in multiple sclerosis patients.

From a healthcare quality standpoint, this study (combined with related analyses mentioned in the discussion) provides valuable information needed for monitoring, training and planning purposes. Since FIM is integrated into the hospital information system, we will be able to analyse admission and outcome trends in all patients, applying longitudinal and timeseries models to the data in order to gain a more comprehensive insight into the situation and reach more reliable conclusions.

\section{Acknowledgement}

The authors are grateful to Robert Cugelj, MSc, Director General of the University Rehabilitation Institute, Republic of Slovenia, for supporting the research.

\section{References}

1. Cohen ME, Marino RJ. The tools of disability outcomes research: functional status measures. Arch Phys Med Rehabil 2000; 81 (12 Suppl 2): S21-9.

2. Brock KA, Vale SJ, Cotton SM. The effect of the introduction of a case-mix-based funding model of rehabilitation for severe stroke: an Australian experience. Arch Phys Med Rehabil 2007; 88: 827-32.

3. Hamilton BB, Granger CV, Sherwin FS, Zielezny M, Tasman JS. A uniform data system for medical rehabilitation. In: Fuhrer MJ, editor. Rehabilitation Outcomes: Analysis and measurement. Baltimore: Brooks, 1987: 137-47.

4. Kidd D, Stewart G, Baldry J, Johnson J, Rossiter D, Petruckevitch A, et al. The Functional Independence Measure: a comparative validity and reliability study. Disabil Rehabil 1995; 17: 10-4.

5. Bottemiller KL, Bieber PL, Basford JR, Harris M. FIM score, FIM efficiency, and discharge disposition following inpatient stroke rehabilitiation. Rehabil Nurs 2006; 31: 22-5.
6. Seel RT, Wright G, Wallace T, Newman S, Dennis L. The utility of the FIM+FAM for assessing traumatic brain injury day program outcomes. J Head Trauma Rehabil 2007; 22: 267-77.

7. Khan F, Pallant JF, Brand C, Kilpatric TJ. Effectiveness of rehabilitiation intervention in persons with multiple sclerosis: a randomised control trial. J Neurol Neurosurg Psychiatry 2008; 79: $1230-5$.

8. Lieberman D, Friger M, Lieberman D. Rehabilitation outcome following hip fracture surgery in elderly diabetics: a prospective cohort study of 224 patients. Disabil Rehabil 2007: 339-45.

9. Gabbe BJ, Simpson PM, Sutherland AM, Williamson OD, Judson $\mathrm{R}, \mathrm{Kossmann} T$, et al. Functional measures at discharge: are they useful predictors of long term outcomes for trauma registries? Ann Surg 2008; 247: 854-9.

10. Muslimovic D, Post B, Speelman JD, Schmand B, de Haan RJ; CARPA Study Group. Determinants of disability and quality of life in mild to moderate Parkinson disease. Neurology 2008; 70 : 2241-7.

11. Oczkowski WJ, Barreca S. The Functional Independence Measure: its use to identify rehabilitation needs in stroke survivors. Arch Phys Med Rehabil 1993; 74: 1291-4.

12. Lin KC, Wu CY, Wei TH, Gung C, Lee CY, Liu JS. Effects of modified constraint-induced movement therapy on reach-tograsp movements and functional performance after chronic stroke: a randomised controlled study. Clin Rehabil 2007; 21: 1075-86.

13. Bowman M, Faux S, Wilson S. Rural inpatient rehabilitation by specialist outreach: comparison with a city unit. Aust J Rural Health 2008; 16: 237-40.

14. Ostwald SK, Swank PR, Khan MM. Predictors of functional independence and stress level of stroke at discharge from inpatient rehabiltiation. J Cardiovasc Nurs 2008; 23: 371-7.

15. Ottenbacher KJ, Hsu Y, Granger CV, Fiedler RC. The reliability of the Functional Independence Measure: a quantitative review. Arch Phys Med Rehabil 1996; 77: 1226-32.

16. Stineman MG, Shea JA, Jette A, Tassoni CJ, Ottenbacher KJ, Fiedler R, et al. The Functional Independence Measure: tests of scaling assumptions, structure, and reliability across 20 diverse impairment categories. Arch Phys Med Rehabil 1996; 77: 1101-8.

17. Tennant A, Penta M, Tesio L, Grimby G, Thonnard JL, Slade A, et al. Assessing and adjusting for cross-cultural validity of impairment and activity limitations scales through differential item functining within the framework of the Rasch model. The PRO-ESor project. Medical Care 2004; 42 (Suppl 1) :I-37-48.

18. Lawton G, Lundgren-Nilsson Å, Biering-Sorensen F, Tesio L, Slade A, Penta M, et al. Cross-cultural validity of FIM in spinal cord injury. Spinal Cord 2006; 44: 746-52.

19. Granger CV, Hamilton BB, Linacre JM, Heinemann AW, Wright BD. Performance profiles of the functional independence measure. Am J Phys Med Rehabil 1993; 72: 84-9.

20. Lundgren-Nilsson $\AA$, Tennant A, Grimby G, Sunnerhagen KS. Cross-diagnostic validity in a generic instrument: an example from the Functional Independence Measure in Scandinavia. Health Qual Life Outcomes 2006; 4: 55

21. Tennant A, Penta M, Tesio L, Grimby G, Thonnard J-L, Slade $A$, et al. Assessing and adjusting for cross-cultural validity of impairment and activity limitation scales through Differential Item Functioning within the framework of the Rasch model: the PRO-ESOR project. Med Care 2004; 42 (1 Suppl): I-37-48.

22. Middel B, van Sonderen E. Statistical significant change versus relevant or important change in (quasi) experimental design: some conceptual and methodological problems in estimating magnitude of intervention-related change in health services research. Int J Integr Care 2002; 2: e15. 
23. Shah S, Vanclay F, Cooper B. Efficiency, effectiveness, and duration of stroke rehabilitation. Stroke 1990; 21: 241-6.

24. Huber PJ. Robust estimation of a location parameter. Ann Math Statist 1964; 35: 73-101.

25. R Development Core Team. R: A Language and Environment for Statistical Computing. Vienna, Austria: R Foundation for Statistical Computing, 2008, URL http://www.R-project.org

26. Venables WN, Ripley BD. Modern Applied Statistics with S. 4th ed. New York: Springer, 2002.

27. Hunter J. Outcome, indices and measurements. In: CJ Goodwill, MA Chamberlain, C Evans, editors. Rehabilitation of the physically disabled adult. 2nd ed. Cheltenham: Stanley Thornes, 1997: 87-100.

28. Wright J, Cross J, Lamb SE. Physiotherapy outcome measures for rehabilitation of elderly people: responsiveness to change of the Rivermead Mobility Index and Barthel Index. Physiotherapy 1998; 84: 216-21.

29. Wheeler DJ. Understanding Variation. 2nd ed. Knoxville: SPC Press, 2000.

30. Vidmar G, Burger H, Marinček Č, Cugelj R. Analysis of data on assessment with the Functional Independent Measure at the Institute for Rehabilitation, Republic of Slovenia. Inf Med Slov 2008; 13: 21-32.

31. Vidmar G. Monitoring functional independence in a rehabilitation hospital: an example of efficient use of a simple mixture distribution model. Inf Med Slov 2009; 14: 19-23.

32. Cook Johnson C. The effects of single and compound violations of data set assumptions when using the oneway, fixed effects analysis of variance and the one concomitant analysis of covariance statistical models. New Orleans: Annual Meeting of the Mid-South Educational Research Association; 1993. Available from: http://eric.ed.gov/ERICDocs/data/ericdocs2sql/ content_storage_01/0000019b/80/15/30/98.pdf.

33. Walters SJ, Brazier JE. What is the relationship between the minimally important difference and health state utility values? The case of the SF-6D. Health Qual Life Outcomes 2003; 1: 4.

34. Middel B, van Sonderen E. Erratum. Int J Integr Care 2008; 8: e72.

35. Haas U, Mayer $\mathrm{H}$, Evers GC. Interobserver reliability of the "Functional Independence Measure" (FIM) in patients with craniocerebral injuries. Pflege 2002; 15: 191-7.

36. Lundgren-Nilsson A, Grimby G, Ring H, Tesio L, Lawton G, Slade $A$, Penta $M$, et al. Cross-cultural validity of functional independence measure items in stroke: a study using Rasch analysis. J Rehabil Med 2005; 37: 23-31.

37. Lundgren-Nilsson A, Tennant A, Grimby G, Sunnerhagen KS. Cross-diagnostic validity in a generic instrument: an example from the Functional Independence Measure in Scandinavia. Health Qual Life Outcomes 2006 23; 4: 55.

38. Gabbe BJ, Sutherland AM, Wolfe R, Williamson OD, Cameron PA. Can the modified functional independence measure be reliably obtained from the patient medical record by different raters? Trauma 2007; 63: 1374-9.

39. Kohler F, Dickson H, Redmond H, Estell J, Connolly C. Agreement of functional independence measure item scores in patients transferred from one rehabilitation setting to another. Eur J Phys Rehabil Med 2009; 45: 479-85. 